\title{
On the Pattern of Currency Blocs in Africa
}

Etienne B. Yehoue 


\title{
IMF Working Paper
}

IMF Institute

\section{On the Pattern of Currency Blocs in Africa}

\author{
Prepared by Etienne B. Yehoue ${ }^{1}$ \\ Authorized for distribution by Roland Daumont
}

March 2005

\begin{abstract}
This Working Paper should not be reported as representing the views of the IMF. The views expressed in this Working Paper are those of the author(s) and do not necessarily represent those of the IMF or IMF policy. Working Papers describe research in progress by the author(s) and are published to elicit comments and to further debate.
\end{abstract}

This paper seeks to elucidate the debate over currency union in Africa. The paper examines whether empirical investigation points to the gradual emergence of currency blocs. Based on the historical data on inflation, trade, and the comovements of prices and outputs, I argue that the emergence of large-scale currency blocs in Africa will follow a gradual path and that this dynamic does not lead to the emergence of a single continental currency at this time. Rather, the pattern which emerges seems to suggest three blocs: one in West Africa, a second around South Africa, and a third in Central Africa. Although little evidence is found supporting the emergence of a single African currency at this time, the emergence of an African currency union is not necessarily precluded, since the ultimate decision to surrender a nation's monetary policy to a supranational institution is not made based solely on economic considerations. I then address the issue of a possible anchor for the union, were it to emerge and opt for an anchorage. I find - based on the trade criterion - that the euro seems to be a good choice.

JEL Classification Numbers: F4, F15, F33

Keywords: Anchor, Currency Bloc, Comovement of Prices and Output, Trade Network Externalities

Author(s) E-Mail Address: eyehoue@imf.org

\footnotetext{
${ }^{1}$ I am grateful to Alberto Alesina, Roland Daumont, Andrew Feltenstein, Jeffrey Frankel, Peter J. Ngubumbullu, Catherine Pattillo, Dani Rodrik, and seminar participants at IMF Institute for useful comments and suggestions. The author is solely responsible, however, for all remaining errors.
} 
I. Introduction

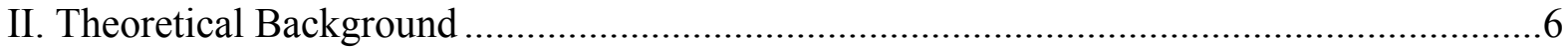

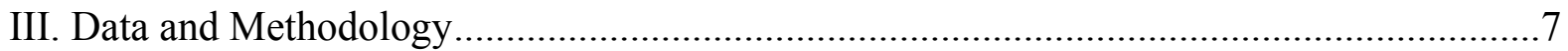

IV. The Dynamic and Pattern of Bloc Formation Based on Inflation, Trade, and Comovements

V. Currency Bloc in Africa: A Potential Anchor............................................................... 13

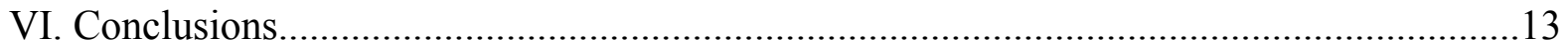

Appendix

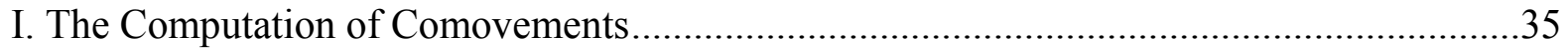

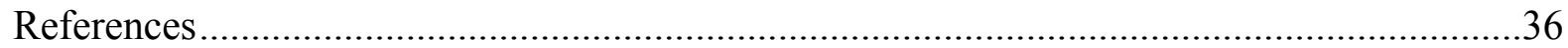

Tables

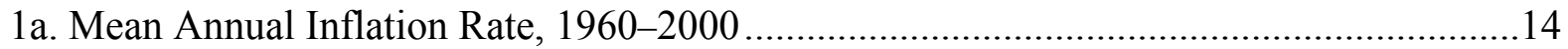

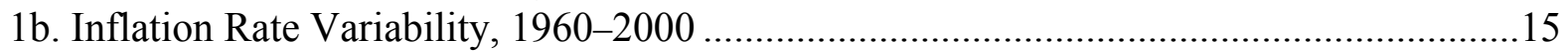

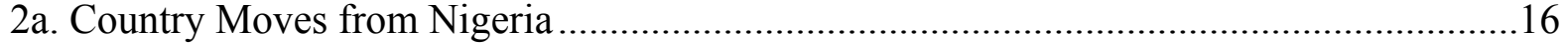

2b. Country Moves from Central African Economic and Monetary Union (CAEMU)...........17

2c. Country Moves from West African Economic and Moneray Union (WAEMU)..............18

2d. Country Moves from Common Monetary Area (CMA) .............................................19

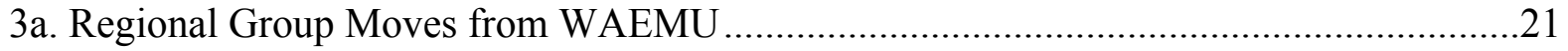

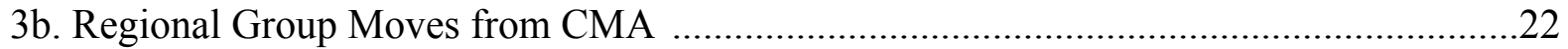

4a. Price Comovement Following Trade Dynamic from WAEMU, 1960-2000 ..................24

4b. Price Comovement Following Trade Dynamic from CMA, 1960-2000 _........................26

5a. Output Comovement Following Trade Dynamic from WAEMU, 1960-2000... .............28

5b. Output Comovement Following Trade Dynamic from CMA, 1960-2000......................30

6. Average Trade-to-GDP Ratio with Major Currency Blocs and Europe-13, 1980-2000 ..31

Figures

1. Dynamic Currency Bloc Formation Based on Individual Country Moves........................32

2. Membership in Major Regional Organizations.............................................................33

3. Dynamic Currency Bloc Formation Based on the Moves of Existing Regional Groups ..34 


\section{INTRODUCTION}

A renewed emphasis on price stability and the need for credible commitment about inflation have placed the question of currency adoption at center stage of the current policy debate. Also, the growth of international trade in goods and assets has raised the transaction benefits from common currencies and increased incentives for common currencies that can be anchored to a major world currency.

In Africa, the case for monetary integration is even stronger. Payments for international transactions necessarily involve exchange of currencies and, hence, exchange rate risk. The costs of, and the ease with which, international transactions are executed depend on a currency's acceptability. Despite the small size of many African countries, the continent is characterized by a remarkable multiplicity of currencies. With 16 countries, West Africa alone uses 10 currencies, ${ }^{2}$ and most of them are not convertible. The lack of convertibility contributes to the high cost of transactions in many subregions, since it costs money and time to exchange one currency for another.

Even where currencies are convertible, exchange rate variability constitutes another set of risks that impedes intraregional trade. The exchange rate policies of many African countries are unstable and unpredictable. Explicit or implicit exchange rate control and other international payment restrictions on the continent promote unrecorded transborder trade in several subregions. For example, as discussed in Ogunkola (2000) a United Nations Economic Commission for Africa (UNECA) study estimates that the level of unrecorded transborder trade is several times that of official intraregional trade in West Africa. Consequently, monetary integration becomes important in addressing the problems of multiplicity of currencies and exchange rate variability that often impede trade flows among African countries.

The degree of negative impact of both currency convertibility and exchange rate variability on intraregional trade flows can be questioned. However, a monetary zone can serve as a disciplinary device and is capable of fostering economic growth. As Ogunkola (2000) points out, guaranteed convertibility and predictable exchange rates are indicators of a stable investment climate, which can stimulate domestic as well as foreign investment. Some studies have reported, for instance, that the experience of the CFA zones ${ }^{3}$ has been beneficial for the member countries

${ }^{2}$ The CFA franc is used in Benin, Burkina Faso, Guinea-Bissau, Côte d'Ivoire, Mali, Niger, Senegal, and Togo; the cedi for Ghana; the delasi in Gambia; the dollar in Liberia; the leone in Sierra Leone; the guinea franc in Guinea; the escudo in Cape Verde; the ouguiya in Mauritania; and the naira for Nigeria. Notice that Guinea-Bissau formerly used the peso but joined the CFA zone in 1997.

${ }^{3}$ CFA stands for Communauté Financière Africaine. The CFA franc is the common currency used by 15 African countries. There are two CFA zones with two different central banks, but both issue the same currency, the CFA franc. The West Africa Economic and Monetary Union (WAEMU) includes Benin, Burkina Faso, Guinea-Bissau, Côte d'Ivoire, Mali, Niger, Senegal, and Togo. The Central Africa Economic and Monetary Union (CAEMU) includes Cameroon, Central African Republic, Chad, Congo, Equatorial Guinea, and Gabon. All but one of the West 
in some respects, as it has reduced instability and led to fewer distortionary policies (see Devarajan and Melo (1987)).

While monetary integration can foster economic growth through price stability and intraregional trade promotion, its implementation is often difficult. However, the recent experience of the European Union (EU) and the apparently successful launch of the euro for 12 member countries constitute a lesson for the African continent. Many scholars ${ }^{4}$ questioned the economic motivation of the emergence for the euro and doubted the European Union's suitability for a monetary union. Nevertheless, European leaders went ahead and launched the euro. Some studies on the European Economic and Monetary Union (EMU) have thus shifted from a normative to a positive perspective, arguing that the goal of EMU emergence is more political rather than economic. ${ }^{5}$ Their key argument is that monetary union is an intermediate step toward political union. In any case, the European experience shows that monetary integration can be implemented despite its difficulties.

African policymakers seem to be following this development. The former continental Organization for African Unity (OAU) has recently undergone reforms, culminating in creation of a new organization, the African Union (AU). In recent years, new political will has emerged to confront the continent's development challenges. The small size of many countries on the continent greatly diminishes their individual bargaining power, reinforcing their incentives to form economic as well as political unions.

Following the European experience, many countries in Africa are discussing entering economic and monetary unions. For example, five West African countries have agreed to create a new common currency by 2005 , which will eventually merge with the West African CFA zone to create a single currency for all of West Africa.

The Southern African Development Community (SADC) is working on a program to establish a common central bank by 2016 and a common currency by 2018. In East Africa, the East Africa Community envisages the establishment of a common market and a monetary union.

Furthermore, the newly launched African Union has seriously considered the idea of adopting a single continental currency. In this regard, the Association of African Central Banks (AACB) has been requested by the African Union to prepare to establish the African Central Bank and a timetable for this. The AACB has suggested a tentative work program that will see the African Central Bank being established by the year 2021 .

African CFA countries are former French colonies, the same being true for the Central African CFA countries. The fifteenth country is Comoros, which issues its own form of CFA franc but maintains a fixed parity with the other two.

${ }^{4}$ See Bayoumi and Eichengreen (1992), Eichengreen (1993), von Hagen and Neumann (1994), de Grauwe and Vanhaverbeke (1993), and Feldstein (1997), among others.

${ }^{5}$ See Alesina and Grilli (1992) and Feldstein (1997). 
The goal of this paper is to examine whether empirical investigation points to the gradual emergence of currency blocs in Africa. In particular, the paper investigates whether there is any economic justification for the emergence of a single African currency at this time. This is done from both normative and positive perspectives. From a normative perspective, the paper uses economic arguments and applies the framework of gradual expansion of currency bloc developed in Yehoue (2004). That paper contends and formalizes the intuition that currency bloc formation is path dependent, that countries join a currency bloc sooner the more they trade with bloc country members, and that each additional member attracts more countries into the bloc in a dynamic way. This dynamic stochastic model is used as the theoretical background for the empirical investigation here. From a positive perspective, the paper extends the economic argument by taking into account what is actually happening with bloc formation on the ground.

Based on the normative argument - in particular, the historical patterns of intra-Africa trade and comovements of prices and outputs - I find little evidence to back the African Union's aspiration to bring about the emergence of a single continental currency at this time. To the contrary, the emerging pattern seems to suggest three blocs: one in West Africa, another around South Africa, and a third in Central Africa, with the remaining sub-Saharan African countries keeping their respective national currencies. However, from a positive perspective, two big blocs could emerge. In particular, the whole of sub-Saharan Africa can be partitioned into two big blocs: one in West and Central Africa and another around South Africa.

A caveat should be highlighted. Although this paper finds little evidence to support the emergence of a single continental currency at this time, this does not necessarily preclude the creation of an African currency union. This is because a nation's decision to surrender its monetary policy to a supranational institution ultimately transcends solely economic considerations, as political will is crucial for currency union formation. The paper then considers the issue of what the best anchor would be if a single currency bloc were to occur in Africa. Among the world's major currencies - the dollar, euro, and yen - the euro seems to be a good candidate for an anchor for the union.

It is worth mentioning that the pattern of currency blocs which emerges from this "model-based" forecast should be seen as indicative and not binding, since currency union membership entails much more than high trade. The key rationale of the paper is simply to investigate whether there is any economic justification for the emergence of a single continental currency at this time.

Also, notice that the analysis puts aside the standard convergence criteria, such as the budget deficit and the debt-to-GDP ratio, which have received substantial attention in the literature. Instead, the paper focuses on the fundamentals - that is, on the trade pattern and the comovements of prices and outputs. Once the criteria about these fundamentals are met, the standard convergence criteria can be met over the short or medium term through fiscal discipline.

The paper is organized as follows. The next section presents the theoretical background underpinning the empirical analysis. Section III presents data and methodology. Section IV analyzes the pattern of currency blocs that emerge from the empirical investigation. Section $\mathrm{V}$ addresses the issue of the best anchor. Section VI concludes the paper. 


\section{THEORETICAL BACKGROUND}

The debate over optimal currency areas, or which countries should form currency areas, began with the pioneering work of Mundell (1961). Many studies have followed suit. For example, Bayoumi (1994) provides a formalization of Mundell's analysis in a multiregion, generalequilibrium model. Recently, Alesina and Barro (2002) extended Mundell's analysis. These works discuss the trade-off between the costs and benefits of currency unions. While they provide a general framework to study currency unions, they did not analyze the timing of joining or the gradual expansion of a currency bloc. Yehoue (2004) proposes a dynamic model that extends Alesina and Barro's (2002) model and tackles the question of gradual expansion of currency blocs. Based on trade network externalities, the model proposes a dynamic game in which currency blocs are endogenously formed in a step by step process of bloc expansion. It formalizes the intuition that currency bloc formation is path dependent and that countries join a currency bloc sooner the more they trade with bloc member countries. Furthermore, each additional member attracts in a dynamic way other countries into the bloc. It highlights that more trade between two countries reduces their output variance and the variance of their relative price. In other words, more trade between a country and its anchor not only increases the marginal benefit from reduced trading cost but also reduces the monetary policy cost that would result from linkage. It suggests that countries' utilities are increasing in trade and that countries that trade more are more likely to form a currency union. The model shows that the dynamic game, which is governed by trade network externalities has an equilibrium. More precisely, the dynamic process of step by step process of bloc expansion leads to a stable bloc configuration.

This paper takes the existence of equilibrium of the dynamic process governing the gradual expansion of currency bloc as given. In other words, I use the model developed in Yehoue (2004) as theoretical background and assume the convergence to a stable equilibrium bloc configuration. Without such a guarantee that the dynamic process of bloc formation converges to a steady state or to a stable bloc configuration, any empirical attempt to investigate dynamic bloc formation might have difficulty justifying an end point. Clearly, it is important to show that the dynamic process of bloc formation converges before moving to an empirical investigation. Based on the intuition that governs that model - that is, countries join a currency bloc sooner the more they trade with bloc member countries, and that each additional member attracts in a dynamic way other countries into the bloc - the exercise in this paper is to play out different scenarios in the context of Africa to uncover the different paths of bloc expansion that emerge. In particular, I evaluate whether currency blocs gradually emerge from an empirical investigation based on trade network externalities. This clearly differs from the one-step currency bloc emergence in Alesina, Barro, and Tenreyro (2002).

The analysis is based on the historical patterns of international trade and of comovements of outputs and prices. In particular, I use the computed shares of intra-Africa trade to GDP and the comovements of prices and outputs to analyze the pattern of currency blocs.

The importance of trade pattern arises from the benefits of reduced transaction costs, which increase with higher trade volume. Based on the intuition highlighted above, this exercise consists of starting from some existing currency blocs or some representative countries, that is potential anchors and of evaluating the dynamic path of expansion. In particular, based on an appropriate trade share threshold, I ask whether some countries would be early joiners, and 
proceed along the dynamic path. A country might fail to meet the criterion of joining at a given round, but as one of its key trading partner meets the criterion and joins, its trade share with the bloc might then increase sufficiently to lead the country to meet the criterion in the next roundand to then join. As it will be shown below, this illustrates how a currency bloc might gradually expand.

The comovements of outputs and prices enter because the costs associated with the loss of monetary autonomy are lower the higher the correlation of shocks between the client and the anchor. In other words, high comovement of prices and output translate into high correlation of shocks. This in turn reduces the cost of losing monetary autonomy and facilitates currency union formation. This holds even where a common central bank selects a policy that taking into account the shocks experienced by all the members of the union. As Alesina, Barro and Tenreyro (2002) point out, what matters is not the correlation of shocks per se, but the variance of the client country's output expressed as a ratio to the anchor country's output. In Africa, the costs associated with the loss of monetary autonomy may not be substantial because stabilization policies are seldom used where exchange rates are flexible. However, Broda's (2004) study of developing countries, including many from Africa, reveals that countries with flexible exchange rate systems show superior performance in the face of terms-of-trade shocks compared to countries with fixed exchange rates. This finding may reflect the benefits of monetary autonomy. At the practical level, the comovements of outputs and prices are computed along the dynamic path dictated by the trade network externalities highlighted earlier.

The empirical investigation is based on the historical patterns. However, a country's decision to join a currency bloc should take into account not only the conditions before joining the bloc, but also the situation that would apply after joining. The economic effects of currency union have been extensively discussed in a recent literature pioneered by Rose (2000) and Frankel and Rose (2002). Despite disagreement over magnitude, a new consensus is emerging that currency union has a positive impact on trade. Thus, taking into consideration the ex post conditions would not affect the countries that would join based only on the historical patterns of trade, but would simply reinforce them. Some countries would have joined if the ex post conditions were accounted for, but will not join based only on the historical patterns of trade. The positive analysis proposed later in this paper-and which implicitly embodies some types of connections between countries covering geographic, colonial links, and economic considerations on the ground - is likely to add these countries that would have been left behind. In the following section, I describe the data and the methodology used.

\section{DATA AND Methodology}

I extract data on bilateral trade from the International Monetary Fund's Direction of Trade Statistics. These data are expressed in real U.S. dollars. I follow Glick and Rose (2002) and Alesina, Barro, and Tenreyro (2002) by deflating the original nominal values of trade by the U.S. consumer price index as well as expressing trade values in 1995 U.S. dollars. Data on trade are available for 1980-2000. I use these data along with data on real GDP from the World Bank's World Development Indicators (WDI) to compute the trade shares between different pairs of African countries. The share is computed as the ratio of real bilateral trade to real GDP. Trade is computed as exports plus imports. In order to deal with the discrepancies in countries' reporting, 
I compute the bilateral trade between two countries $i$ and $j$ as being the average of trades reported by countries $i$ and $j$.

Data on outputs and prices are from the $W D I$ data base. I form a panel of countries with yearly data on outputs and prices from 1960 to 2000. I use shorter periods where data are missing. For output, I use real per capita GDP expressed in 1995 U.S. dollars. To compute relative prices, I follow Alesina, Barro, and Tenreyro (2002) and use a form of real exchange rate relating to the price level for gross domestic product. The measure is the purchasing power parity (PPP) for GDP divided by the U.S. dollar exchange rate. For a given country $i$, it measures how many units of U.S. output can be purchased with one unit of country $i$ 's output, that is, it measures the relative price of country $i$ 's output with respect to that of the United States. By definition this relative price is always one when country $i$ is the United States. Notice that in the first instance, this measure expresses the price level in country $i$ relative to that in the United States. I then compute the relative prices between countries $i$ and $j$ by dividing the value for country $i$ by that for country $j$. Inflation is computed as the growth rate of the GDP deflator from the WDI data base.

For the comovements of output and price, I compute a measure of lack of comovement of relative output and of relative price. A lower value of these measures suggests a greater comovement of outputs and prices. The computations and related details are presented in the appendix.

\section{The Dynamic and Pattern of Bloc Formation Based on INFLATION, TRADE, AND COMOVEMENTS}

This section sketches out the natural currency blocs that would emerge based on the dynamic governed by the network externalities operating through trade channels. I also investigate the corresponding comovements of prices and outputs.

I begin by presenting average inflation for 1960-2000 in order, ranging from countries with hyperinflation to countries with low inflation (see Table 1a). This is important to identify the potential unions or countries that can serve as starting blocs in the dynamic bloc formation. They must be good candidates in terms of low and stable inflation. After all, one key reason to join a bloc or anchor one country's currency to another is the need for an anti-inflationary commitment. While overall inflation is reasonably low for the continent, several countries have experienced high inflation. Over the study period, countries like Angola, Democratic Republic of the Congo, and Uganda were characterized by inflations ranging from 56 to 1,036 percent. Overall, of 53 African countries, 3 had average inflation rates above 50 percent, 12 had average inflation rates above 20 percent, and 24 had average inflation rates exceeding 10 percent. Table $1 \mathrm{~b}$ presents inflation variability in the same order as Table 1a. Since average inflation and inflation variability are positively correlated, 12 of the top 15 in Table 1a are also in the top 15 of Table $1 b$.

As a starting point, I consider the existing currency unions and some representative countries that are potential anchors. More precisely, I consider the West African CFA zone, the Central African CFA zone, Nigeria with the naira, and the rand zone centered on South Africa. While the other zones appear to be viable anchors because of their low inflation (approximately 5.5 percent for 
the West Africa CFA zone, 7.5 percent for the Central African CFA, and 10 percent for the rand zone) Nigeria has a relatively high inflation, with average inflation of about 18 percent during 1960-2000.

Before starting the dynamic of bloc formation based on trade channels, notice that intra-African trade is otherwise at a very low level. Setting aside the role of mechanism of restraint that a monetary union might play-something hard to appreciate ex-ante - the African countries could form the currency union they aspire to, either to lower borrowing or trade costs. In reality however, there is no borrowing whatsoever between African countries, leaving trade as one key for forming a currency union. Hence, despite the low intra-African trade, using this low level of trade to analyze the potential bloc patterns in Africa is justifiable. Based on the figure of recorded intra-African trade, ${ }^{6}$ I use an arbitrary threshold of 2 percent ${ }^{7}$ for the ratio of trade to GDP to see what the dynamic of currency bloc formation might look like. In other words, everything else being equal, if the ratio of recorded total bilateral trade to GDP between a country $i$ and a potential anchor $j$ exceeds 2 percent, then country $i$ might be willing to join country or bloc $j$. This threshold may appear too low at first glance, but no one familiar with the volume of trade between African countries will be surprised. On average, the bilateral trade-toGDP ratio between any two African countries is about 0.59 percent. The low intra-Africa trade has received some attention in the literature. For example, Foroutan and Pritchett (1993), use 19 African countries to find that intra-African trade is no lower than would be expected in light of low income and poor infrastructure in so many African countries. Thus, while my threshold might seem low, it is nonetheless reasonable in the context of Africa. Accordingly, as will be shown below, I find no economic justification for a single continental currency to emerge in Africa. Some readers might prefer a higher threshold; yet this does not alter the key point of this paper, that is, no economic justification for the emergence of a single currency for Africa. To the contrary, it simply reinforces it.

Using Nigeria as a regional anchor, the dynamic based on trade criteria shows that only Niger and Côte d'Ivoire are good candidates for joining Nigeria. The results are reported in Table 2a. In addition to Nigeria's relatively high inflation, this argues against Nigeria as a good regional anchor at this time. This scenario is unlikely to occur, since it implies that Niger and Côte d'Ivoire would individually withdraw from the CFA arrangements in the first place to form a currency union with Nigeria.

Using the Central African CFA zone (also known as the Central African Economic and Monetary Union, CAEMU) as the starting point, the analysis reveals that no country would join this bloc, as the highest trade share with the bloc is only about 1 percent. Table $2 \mathrm{~b}$ presents the results. This also reflects that CAEMU is not a good regional anchor. The most interesting configurations emerge when the West African CFA zone and the rand zone are chosen as the

\footnotetext{
${ }^{6}$ Notice that there is undoubtedly considerable informal trade that is not recorded.

${ }^{7}$ Notice that this study is not the first to make use of an arbitrary cut-off choice. Alesina, Barro, and Tenreyro (2002) for instance, investigating the best anchor among the world major currencies for different countries use a cut-off of four percentage point higher for trade share. See their paper for more details.
} 
starting points. Tables $2 \mathrm{c}, 2 \mathrm{~d}, 3 \mathrm{a}$, and $3 \mathrm{~b}$ present the average trade-to-GDP ratios for countries and regional groups according to the gradual bloc expansion, which emerges when using the West African CFA zone and the rand zone as the starting points.

Figures 1 and 3 present the corresponding bloc configurations. Tables $2 \mathrm{c}$ and $2 \mathrm{~d}$ are based on individual country moves, while Tables $3 \mathrm{a}$ and $3 \mathrm{~b}$ are based on the existing regional group moves. Starting from the West African CFA zone (also known as the West African Economic and Monetary Union, WAEMU), and based on each country's individual decision, the early joiners turn out to be The Gambia, Mauritania, Liberia, Ghana, and Nigeria, with average trade shares varying from 5.47 percent (The Gambia) to 2.29 (Nigeria). This would lead to a bloc comprised of the WAEMU and these five countries. After computing the trade shares of the remaining African countries with this new larger bloc, the next candidates to join are Sierra Leone and Equatorial Guinea. However, the latter will not join because Equatorial Guinea belongs to the Central African CFA zone and its trade share of 9.67 percent with this zone is substantially higher than its trade share of 2.14 percent with WAEMU and the five other countries. This leads to a bloc comprised of The Gambia, Mauritania, Liberia, Ghana, Nigeria, Sierra Leone, and the WAEMU member countries. After computing the trade shares of the remaining countries with this expanded bloc, it turns out, based on the trade criteria defined above, that no other country would be willing to join the bloc, since the highest trade share in this case is Guinea, with 1.86 percent.

Starting from the rand zone (also known as the Common Monetary Area (CMA), comprised of South Africa, Namibia, Swaziland, and Lesotho), ten countries would be early joiners. They are Malawi, Mozambique, Zimbabwe, Zambia, Mauritius, Seychelles, Liberia, Comoros, Angola, and Tanzania, with average trade shares varying from 21.42 percent (Malawi) to 2.23 percent (Tanzania). Notice that Liberia has a trade share of 4.84 percent with CMA and 4.22 percent with WAEMU. However, though Liberia trades slightly more with CMA, it is unlikely to join the CMA because of geographical and perhaps political considerations. The trade share difference seems insufficient to lead Liberia toward CMA, but rather, Liberia is likely to join WAEMU as mentioned above. Therefore, the emerging bloc comprises the CMA member countries and the previous ten countries. I then compute the trade shares of the remaining African countries with this expanded bloc and find five next joiners. These are: Kenya, Botswana, São Tomé and Príncipe, Democratic Republic of the Congo, and Burundi, with average trade shares varying from around 4 percent (Kenya) to 2.07 percent (Burundi). I continue the process and compute the average trade shares of the remaining countries with the new bloc that emerges from the previous expansion. It turns out that Uganda, Rwanda, and Somalia would be the next joiners, with respectively, 5, 4.51, and 2.16 percent as trade shares. To this new expanded bloc, only Djibouti would join in the next round with a trade share of more than 8 percent. In the following round, no other country satisfies the criteria to join.

To summarize, this dynamic leads to three blocs: one for the West African States; a second bloc around South Africa and comprising of the Eastern and Southern African States; and a third bloc, which is the existing Central Africa CFA zone. This bloc configuration, which emerges from country individual moves, is presented in Figure 1. Notice from the above analysis that the final outcome or the blocs that emerge differ depending on the starting point. For example, starting from Nigeria, leads to a different bloc than starting from the WAEMU or CAEMU. This highlights the path dependency of currency bloc formation. One consequence of this is that a 
region can end up with one equilibrium rather than another, with one being Pareto dominant in terms of welfare. But determining which equilibrium or outcome might best improve the welfare of the region is beyond the scope of this paper. The analysis so far has been normative, that is, it describes how currency blocs should normally emerge in Africa based on reasonable threshold. But taking into account the reality on the ground, that is, what is actually happening, may not lead exactly to the same outcome.

I now turn to this positive analysis. The African continent has some particularities, namely, an ongoing dynamic in terms of regional grouping. Taking that into account might be worthwhile. A number of economic and regional organizations in Africa overlap sometimes compete or are conflictual; and some are clearly more effective than others. I propose here a positive analysis that takes these facts into account. This is important because historical or cultural ties might also affect some country's decision to join a bloc. Consequently, the move to join a bloc might well be based on the existing regional groups. Therefore, the dynamic here will be based on the gradual moves of the existing economic or regional organizations. In other words, the threshold criterion will now be applied to existing regional groups. Before turning to that however, I show in Figure 2 existing and effective regional groups and how they overlap. This helps to clarify the dynamic based on the existing regional groups.

Turning to the dynamic based on group moves, the bloc configuration that emerges differs slightly from that which emerges from the earlier dynamic based on country's individual moves. Indeed, starting from the WAEMU, which is part of the Economic Community of West African States (ECOWAS), it turns out that the next mover would be the rest of ECOWAS, that is, the group formed by ECOWAS members not members of WAEMU, with a trade share of 2.27 percent (see Table 3a). Once this ECOWAS currency bloc is formed, the next mover according to the trade criterion would be Mauritania, which was formerly a member but left ECOWAS in 1999. Continuing the process, the next group with the highest trade share with the bloc ECOWAS and Mauritania is CAEMU, with a trade share of only 1.51 percent. This does not exceed the threshold of 2 percent; and as a result, CAEMU should not join the bloc. However, notice that CAEMU is the Central African CFA zone that already shares the same currency with WAEMU. The difference is that each of them has its own central bank and issues its own CFA franc, both of which are pegged to the French franc (now the euro). In fact, Nigeria is the only country geographically separating the two zones. If WAEMU with other West African States, including Nigeria, were to form a currency union as I found earlier, the two CFA zones would now be compacted; and there would be no reason for CAEMU not to join this union since it is already sharing the same currency with WAEMU. Therefore, even though CAEMU fails to meet the trade criterion, this positive analysis suggests that it might join the bloc. Hence I use a dashed line in Figure 3 to link CAEMU to the bloc ECOWAS and Mauritania.

Now, starting from the CMA, which is part of the Southern African Development Community (SADC), it turns out that the group formed by the rest of SADC country members has the highest trade share (7.04 percent) with the CMA. Hence, this group will join CMA to form a bigger currency bloc comprising all the SADC members. Before proceeding further, notice that the SADC and the Cross Border Initiative (CBI) overlap with some members belonging to the two organizations. Consequently, some members of CBI are already members of the previous currency bloc. I compute the trade shares of the remaining regional groups with SADC currency bloc, and I find that the group formed by the rest of the CBI member countries comes with the 
highest trade share of 2.53 percent. Hence, the group will join the SADC bloc, leading to a bigger bloc comprising all the SADC and CBI member countries. Notice that São Tomé and Príncipe, which belongs neither to SADC nor CBI, might also join the bloc because its trade share of 4.04 exceeds the threshold. Continuing the procedure, it turns out that no other group meets the criteria to the join the SADC, CBI, and São Tomé and Príncipe currency bloc.

This analysis leads to two big blocs: one in western and central Africa, the other in eastern and southern Africa. In fact, almost the entire sub-Saharan Africa partitions into two blocs. The exceptions are Djibouti, Ethiopia, Eritrea, and Sudan. Along with the North African countries, these countries would keep their individual currencies. This bloc configuration is summarized in Figure 3. Based on the normative and positive arguments as elaborated in this study, it appears unclear that a single continental currency would emerge, despite the aspiration of the newly launched African Union.

I now discuss how the comovements of outputs and prices support the finding above. Tables $4 \mathrm{a}$ and $4 \mathrm{~b}$ report the measures of comovements of prices following the dynamics generated by trade. Notice that a low number means more comovements. The CFA zone country members, which share the same currency, have a high degree of price comovement. Some northern African countries, such as Tunisia, Morocco, and Algeria, also have relatively high price comovements with ECOWAS bloc, suggesting some justification to join a sub-Saharan currency bloc, as I argue in the subsection below. The rand zone country members also have a high degree of price comovement. Some early joiners to CMA, such as Botswana and Mauritius, also have relatively high price comovements with CMA.

Some caveats are necessary. Mauritania was an early joiner to WAEMU based on trade. While it has a relatively high price comovement with WAEMU, other early joiners, such as The Gambia, Ghana, and Nigeria, have relatively low price comovements with WAEMU. The same holds for Malawi, Mozambique, and Zimbabwe, which are early joiners to CMA. One explanation is that more trade always meaning more comovements of prices and outputs may not be a settled issue. For example, Frankel and Rose (1998) argue that more trade leads to more correlated business cycles, while Krugman (1993) argues the opposite. However, the theory predicts that more intraindustry trade likely leads to more comovements and that more inter-industry trade likely stimulates more sectoral specialization across countries, leading to lower comovements of prices and outputs. According to Krugman (1993), this is because industry-specific shocks would become country specific shocks. The intra-African trade exhibits very little of the intra-industry pattern. This may explain the low price comovements for the countries mentioned above.

Tables $5 \mathrm{a}$ and $5 \mathrm{~b}$ present the measures of comovements of outputs following the dynamics generated by trade. The overall picture is reasonably similar to that of prices. The CFA zone member countries have relatively high comovement of outputs, though some non-CFA countries such as Kenya, Algeria, and Egypt comove better in terms of outputs with WAEMU. The rand zone country members also have relatively high comovement of outputs. The early joiners, which exhibited some peculiarities mentioned above, perform better in terms of comovement of output. For example, while Ghana and Nigeria exhibit a lack of price comovements of the order of 31 and 38 percent respectively, they exhibit a lack of output comovement only of the order of 6 percent each. Guinea-Bissau did not perform well in terms of comovements of prices and outputs with WAEMU because it joined the union only in 1997. 
In this section, I have combined an economic argument with the on-the-ground reality characterized by the existing regional groupings in order to analyze the pattern of currency blocs. No evidence can be found for the emergence of a single continental currency in Africa. However, a single currency could nevertheless emerge in Africa. After all, the ultimate decision of surrendering some policy decisions - especially monetary policy - to a supranational institution goes beyond economic considerations. It involves politics. For example, prior to the introduction of the euro, most studies concluded that the European Union was unsuitable for a monetary union as mentioned in the introduction. Despite these findings, the euro was introduced and seems to be successful so far. This highlights the importance of political will in the formation of a monetary union.

\section{Currency Bloc in Africa: A Potential AnChor}

In this section, I investigate which of the major currencies - the dollar, euro or the yen - would be the best anchor for an African currency union, if one were ever to emerge. Indeed, one key characteristic of most small, open economies is that the bulk of their international commerce and finance must be transacted with the advanced industrial nations' currencies rather than their own. Taking into account anti-inflationary commitment, an African currency union may therefore need to choose a major currency as its anchor. For this choice of anchor, the pattern of African international trade greatly matters. For the African Union, I computed the average trade-to-GDP ratio with the major currency blocs: the dollar, euro, and yen. Table 6 reports the results. It turns out that Africa's trade share with the European Economic and Monetary Union (EMU) is approximately 22 percent, which is much higher than that with the United States (around 7 percent), or with Japan (around 2.5 percent). If the United Kingdom were to join the EMU, this share would rise to around 27 percent. Therefore, the euro seems to be a good choice of anchor for the African Union.

\section{Conclusions}

The basic message of this paper is twofold. First, based on the notions that currency bloc formation is path dependent and that trade network externalities help explain the gradual expansion of currency blocs (developed in Yehoue, 2004), this paper evaluates whether currency blocs gradually emerge from an empirical investigation in Africa. Based on the historical data on inflation, trade, and the comovements of prices and outputs, I argue that the emergence of currency bloc(s) in Africa will follow a gradual path and that this dynamic does not lead to the emergence of a single continental currency at this time. Although this contrasts with the aspiration of the newly launched African Union, the emergence of an African currency union is not necessarily precluded, because the ultimate decision to surrender a nation's monetary policy to a supranational institution goes beyond solely economic considerations and involves political will.

Second, the paper investigates which of the world's major currencies - the dollar, euro, or the yen - would be the best anchor for an African Monetary Union. Were the union to emerge and opt for an anchorage, the analysis suggests, a good anchor would be the euro. 
Table 1a. Mean Annual Inflation Rate, 1960-2000 1/ (In percent)

\begin{tabular}{lr}
\hline \multicolumn{1}{c}{ High-Inflation Countries (Ranked by Inflation) } \\
\hline \hline Congo, Dem. Rep. of & 1036.22 \\
Angola & 819.68 \\
Uganda & 55.76 \\
São Tomé and Príncipe & 42.35 \\
Mozambique & 36.77 \\
Guinea-Bissau & 31.65 \\
Sudan & 31.12 \\
Zambia & 30.42 \\
Somalia & 29.43 \\
Ghana & 28.33 \\
Sierra Leone & 26.67 \\
Tanzania & 20.97 \\
Nigeria & 17.62 \\
Malawi & 14.69 \\
Zimbabwe & 12.81 \\
Eritrea & 12.18 \\
Madagascar & 12.16 \\
Algeria & 12.07 \\
Guinea & 12.00 \\
Equatorial Guinea & 11.78 \\
Swaziland & 11.44 \\
Namibia & 10.93 \\
Rwanda & 10.91 \\
South Africa & 10.31 \\
Libya & 9.69 \\
Gambia, The & 9.24 \\
Lesotho & 9.00 \\
Botswana & 8.91 \\
Egypt, Arab Rep. & 8.87 \\
Kenya & 8.48 \\
Gabon & 8.47 \\
Mauritius & 8.36 \\
Burundi & 4.32 \\
Congo, Rep. of & 8.07 \\
Mali & 7.84 \\
Central African Republic & 7.31 \\
Seychelles & 7.12 \\
Ethiopia & 6.63 \\
Mauritania & 6.34 \\
Cameroon & 6.26 \\
Tunisia & 6.24 \\
Côte d'Ivoire & 6.20 \\
Comoros & 6.12 \\
Benin & 6.13 \\
Togo & 5.89 \\
Chad & 5.44 \\
Niger & 5.38 \\
Morocco & 5.32 \\
Senegal & 5.19 \\
Cape Verde & 5.09 \\
Burkina Faso & \\
Liberia & \\
Djibouti & \\
\hline & \\
&
\end{tabular}

1/ Based on GDP deflators. 
Table 1b. Inflation Rate Variability, 1960-2000 1/ (In percent)

\begin{tabular}{|c|c|}
\hline \multicolumn{2}{|c|}{$\begin{array}{l}\text { Countries with High Inflation Variability } \\
\text { (Ranked by Standard Deviation of Inflation ) }\end{array}$} \\
\hline Congo, Dem. Rep. of & 4480.18 \\
\hline Angola & 1467.90 \\
\hline Uganda & 63.33 \\
\hline Somalia & 44.44 \\
\hline Zambia & 40.26 \\
\hline Mozambique & 38.97 \\
\hline Guinea-Bissau & 32.76 \\
\hline Sierra Leone & 31.38 \\
\hline Sudan & 31.38 \\
\hline São Tomé and Príncipe & 25.27 \\
\hline Ghana & 24.07 \\
\hline Equatorial Guinea & 22.90 \\
\hline Libya & 20.93 \\
\hline Nigeria & 20.18 \\
\hline Rwanda & 17.07 \\
\hline Gabon & 17.03 \\
\hline Malawi & 16.29 \\
\hline Zimbabwe & 14.03 \\
\hline Congo, Rep. of & 13.04 \\
\hline Algeria & 12.92 \\
\hline Guinea & 11.80 \\
\hline Ethiopia & 10.82 \\
\hline Mauritius & 10.31 \\
\hline Madagascar & 10.18 \\
\hline Togo & 10.15 \\
\hline Eritrea & 10.05 \\
\hline Gambia, The & 10.03 \\
\hline Côte d'Ivoire & 9.76 \\
\hline Niger & 9.18 \\
\hline Chad & 9.17 \\
\hline Seychelles & 8.92 \\
\hline Central African Republic & 8.57 \\
\hline Burundi & 8.27 \\
\hline Kenya & 7.49 \\
\hline Lesotho & 7.47 \\
\hline Mali & 7.43 \\
\hline Tanzania & 7.32 \\
\hline Egypt, Arab Rep. & 6.96 \\
\hline Benin & 6.96 \\
\hline Liberia & 6.48 \\
\hline Cameroon & 6.11 \\
\hline Botswana & 6.06 \\
\hline South Africa & 5.84 \\
\hline Namibia & 5.82 \\
\hline Senegal & 5.65 \\
\hline Burkina Faso & 5.56 \\
\hline Comoros & 5.43 \\
\hline Morocco & 4.83 \\
\hline Tunisia & 4.81 \\
\hline Mauritania & 4.18 \\
\hline Swaziland & 4.02 \\
\hline Cape Verde & 2.20 \\
\hline Djibouti & 1.94 \\
\hline
\end{tabular}

1/ Standard Deviation of annual inflation rates, based on GDP deflators. 
Table 2a. Country Moves from Nigeria

Average Trade-to-GDP Ratio with Nigeria, 1980-2000

(In percent)

\begin{tabular}{ll}
\hline \multicolumn{2}{c}{ High Trade-Ratio Countries } \\
\hline \hline Niger & 4.34 \\
Côte d'Ivoire & 3.72 \\
Senegal & 1.96 \\
Togo & 1.66 \\
Chad & 0.76 \\
Benin & 0.74 \\
Cameroon & 0.62 \\
Burkina Faso & 0.54 \\
Congo, Dem. Rep. of & 0.35 \\
Liberia & 0.31 \\
Equatorial Guinea & 0.26 \\
South Africa & 0.26 \\
Gabon & 0.20 \\
Mali & 0.18 \\
Congo, Rep. of & 0.18 \\
Comoros & 0.17 \\
Morocco & 0.17 \\
Guinea-Bissau & 0.07 \\
Central African Rep. & 0.05 \\
Angola & 0.04 \\
\hline & \\
\hline \hline CMA and WAEMU and CAEMU & 3.18 \\
WAEMU and CAEMU & 2.93 \\
CMA and WAEMU & 2.74 \\
WAEMU & 2.49 \\
CMA and CAEMU & 0.69 \\
CAEMU & 0.44 \\
CMA & 0.25 \\
SADC & 0.20 \\
\hline & \\
\hline African Blocs 1/ & \\
\hline & \\
\hline
\end{tabular}

1/ Notes: CMA denotes Common Monetary Area, WAEMU the West African Economic and Monetary Union, ECOWAS the Economic Community of West African States, and SADC the Southern African Development Community. 
Table 2b. Country Moves from Central African Economic and Monetary Union (CAEMU) Average Trade-to-GDP Ratio with CAEMU, 1980-2000

(In percent)

\begin{tabular}{lc}
\hline \multicolumn{2}{c}{ High Trade-Ratio Countries } \\
\hline \hline Senegal & 1.22 \\
Guinea & 1.04 \\
Mauritania & 0.86 \\
Côte d'Ivoire & 0.68 \\
São Tomé and Príncipe & 0.57 \\
Togo & 0.48 \\
Morocco & 0.32 \\
Benin & 0.25 \\
Nigeria & 0.23 \\
Congo, Dem. Rep. of & 0.21 \\
Guinea-Bissau & 0.20 \\
Angola & 0.16 \\
Gambia, The & 0.14 \\
Tunisia & 0.12 \\
Burkina Faso & 0.08 \\
Niger & 0.07 \\
South Africa & 0.06 \\
Ghana & 0.05 \\
Malawi & 0.03 \\
Mali & 0.03 \\
\hline & \\
\hline \hline CMA and WAEMU and Group of five 1/ & 0.89 \\
CMA and WAEMU & 0.62 \\
WAEMU & 0.56 \\
WAEMU and Group of five & 0.37 \\
ECOWAS & 0.36 \\
CMA and Group of five & 0.32 \\
Group of five & 0.26 \\
SADC & 0.06 \\
CMA & 0.06 \\
\hline $1 /$ African Blocs & \\
\hline
\end{tabular}

1/ Group of five: The Gambia, Ghana, Guinea, Nigeria and Sierra Leone. 
Table 2c. Country Moves from West African Economic and Monetary Union (WAEMU) Average Trade-to-GDP Ratio with WAEMU, 1980-2000 (In percent)

\begin{tabular}{lc}
\hline \multicolumn{2}{c}{ High Trade-Ratio Countries } \\
\hline \hline Gambia, The & 5.47 \\
Mauritania & 5.22 \\
Liberia & 4.22 \\
Ghana & 2.56 \\
Nigeria & 2.29 \\
Equatorial Guinea & 1.54 \\
Guinea & 1.50 \\
Sierra Leone & 1.33 \\
Cape Verde & 1.30 \\
Gabon & 1.21 \\
São Tomé and Príncipe & 0.76 \\
Cameroon & 0.64 \\
Congo, Republic of & 0.61 \\
Central African Rep. & 0.43 \\
Angola & 0.27 \\
\hline
\end{tabular}

Table 2c (continued). Country Moves from WAEMU Average Trade-to-GDP Ratio with WAEMU, Gambia, Mauritania, Liberia, Ghana, and Nigeria, 1980-2000

(In percent)

\begin{tabular}{lc}
\hline \multicolumn{2}{c}{ High Trade-Ratio Countries } \\
\hline \hline Sierra Leone & 4.87 \\
Equatorial Guinea & 2.14 \\
Guinea Average & 1.86 \\
Cameroon & 1.42 \\
Gabon & 1.42 \\
Cape Verde & 1.34 \\
Chad & 1.02 \\
Congo, Rep. of & 0.94 \\
São Tomé and Príncipe & 0.78 \\
Congo, Dem. Rep. of & 0.71 \\
Central African Rep. & 0.49 \\
Angola & 0.44 \\
Morocco & 0.39 \\
Tunisia & 0.31 \\
Algeria & 0.28 \\
\hline
\end{tabular}


Table 2d. Country Moves from Common Monetary Area (CMA) Average Trade-to-GDP Ratio with CMA, 1980-2000

(In percent)

\begin{tabular}{lc}
\hline \multicolumn{2}{c}{ High Trade-Ratio Countries } \\
\hline \hline Malawi & 21.42 \\
Mozambique & 19.46 \\
Zimbabwe & 14.61 \\
Zambia & 11.31 \\
Mauritius & 8.18 \\
Seychelles & 7.04 \\
Comoros & 3.98 \\
Angola & 3.02 \\
Tanzania & 2.23 \\
São Tomé and Príncipe & 1.96 \\
Kenya & 1.95 \\
Congo, Dem. Rep. of & 1.84 \\
Ghana & 1.07 \\
Togo & 1.05 \\
\hline
\end{tabular}

Table 2d (continued). Country Moves from CMA

Average Trade-to-GDP Ratio with CMA, Malawi, Mozambique, Zimbabwe, Zambia, Mauritius, Seychelles, Comoros, Angola, and Tanzania, 1980-2000

(In percent)

\begin{tabular}{ll}
\hline \multicolumn{2}{c}{ High Trade-Ratio Countries } \\
\hline \hline Kenya & 3.86 \\
Botswana & 3.74 \\
São Tomé and Príncipe & 2.45 \\
Congo, Dem. Rep. of & 2.38 \\
Burundi & 2.07 \\
Madagascar & 1.87 \\
Togo & 1.25 \\
Ghana & 1.24 \\
Congo, Rep. of & 1.21 \\
Rwanda & 1.10 \\
Mali & 0.98 \\
Uganda & 0.89 \\
Cape Verde & 0.81 \\
Côte d'Ivoire & 0.75 \\
Nigeria & 0.71 \\
\hline
\end{tabular}


Table 2d (continued). Country Moves from CMA

Average Trade-to-GDP Ratio with CMA, Malawi, Mozambique, Zimbabwe, Zambia, Mauritius, Seychelles, Comoros, Angola, Tanzania, Kenya, Botswana, São Tomé and Príncipe, Democratic Republic of the Congo, and Burundi, 1980-2000

(In percent)

\begin{tabular}{lc}
\multicolumn{2}{c}{ (In percent) } \\
\hline \hline Uganda & High Trade-Ratio Countries \\
Rwanda & 5.00 \\
Somalia & 4.51 \\
Madagascar & 2.16 \\
Congo, Rep. of & 1.93 \\
Djibouti & 1.77 \\
Togo & 1.63 \\
Ghana & 1.33 \\
Sudan & 1.25 \\
Mali & 1.21 \\
Côte d'Ivoire & 0.98 \\
Nigeria & 0.92 \\
Cape Verde & 0.87 \\
Mauritania & 0.84 \\
Sierra Leone & 0.65 \\
\hline
\end{tabular}

Table 2d (concluded). Country Moves from CMA

Average Trade-to-GDP Ratio with CMA, Malawi, Mozambique, Zimbabwe, Zambia, Mauritius, Seychelles, Comoros, Angola, Tanzania, Kenya, Botswana, São Tomé and Príncipe, Democratic Republic of the Congo, Burundi, Uganda, Rwanda, and Somalia, 1980-2000

(In percent)

\begin{tabular}{lc}
\hline \multicolumn{2}{c}{ High Trade-Ratio Countries } \\
\hline \hline Djibouti & 8.13 \\
Madagascar & 1.93 \\
Congo, Rep. of & 1.77 \\
Togo & 1.33 \\
Ghana & 1.25 \\
Sudan & 1.23 \\
Mali & 0.98 \\
Côte d'Ivoire & 0.92 \\
Nigeria & 0.87 \\
Cape Verde & 0.84 \\
Mauritania & 0.65 \\
Sierra Leone & 0.64 \\
Ethiopia & 0.64 \\
Gambia, The & 0.62 \\
Central African Rep. & 0.59 \\
\hline
\end{tabular}


Table 3a. Regional Groups Moves from WAEMU Average Trade-to-GDP Ratio with WAEMU, 1980-2000 (In percent)

\begin{tabular}{lc}
\hline \multicolumn{2}{c}{ High Trade-Ratio Countries } \\
\hline \hline Gambia, The & 5.47 \\
Mauritania & 5.22 \\
Liberia & 4.22 \\
Ghana & 2.56 \\
Nigeria & 2.29 \\
Equatorial Guinea & 1.54 \\
Guinea & 1.50 \\
Sierra Leone & 1.33 \\
Cape Verde & 1.30 \\
Gabon & 1.21 \\
São Tomé and Príncipe & 0.76 \\
Cameroon & 0.64 \\
Congo, Rep. of & 0.61 \\
Central African Rep. & 0.43 \\
Angola & 0.27 \\
\hline \multicolumn{1}{c}{ Regional Groups 1/ } \\
\hline ECOWAS Rest & 2.27 \\
Group of 5 & 2.21 \\
CAEMU & 0.74 \\
North Africa & 0.13 \\
SADC & 0.07 \\
SADC, CBI REST and São Tomé and Príncipe & 0.07 \\
CMA & 0.06 \\
\hline
\end{tabular}

Table 3a (continued). Regional Groups Moves from WAEMU Average Trade-to-GDP Ratio with ECOWAS \& MAURITANIA, 1980-2000 (In percent)

\begin{tabular}{lc}
\hline \multicolumn{2}{c}{ High Trade-Ratio Countries } \\
\hline \hline Equatorial Guinea & 2.14 \\
Cameroon & 1.85 \\
Gabon & 1.48 \\
Chad & 1.02 \\
Congo, Rep. of & 0.97 \\
São Tomé and Príncipe & 0.78 \\
Congo, Dem. Rep. of & 0.71 \\
Central African Rep. & 0.49 \\
Angola & 0.44 \\
Morocco & 0.41 \\
Tunisia & 0.32 \\
Algeria & 0.28 \\
Comoros & 0.24 \\
South Africa & 0.23 \\
Mauritius & 0.21 \\
\hline \multicolumn{1}{c}{ Regional Groups } \\
\hline CAEMU & 1.51 \\
SADC & 0.24 \\
CMA SADC, CBI REST and São Tomé and Príncipe & 0.23 \\
North Africa & 0.22 \\
\hline
\end{tabular}

1/ CBI Rest: Burundi, Comoros, Kenya, Madagascar, Rwanda, São Tomé and Príncipe and Uganda. 
Table 3b. Regional Group Moves from CMA Average Trade-to-GDP Ratio with CMA, 1980-2000 (In percent)

\begin{tabular}{lc}
\hline \multicolumn{2}{c}{ High Trade-Ratio Countries } \\
\hline \hline Malawi & 21.42 \\
Mozambique & 19.46 \\
Zimbabwe & 14.61 \\
Zambia & 11.31 \\
Mauritius & 8.18 \\
Seychelles & 7.04 \\
Liberia & 4.84 \\
Comoros & 3.98 \\
Angola & 3.02 \\
Tanzania & 2.23 \\
São Tomé and Príncipe & 1.96 \\
Kenya & 1.95 \\
Congo, Dem. Rep. of & 1.84 \\
Ghana & 1.07 \\
Togo & 1.05 \\
\hline & \\
\hline \hline SADC (Rest) & 7.04 \\
CBI (Rest) & 1.24 \\
Group of 5 & 0.66 \\
ECOWAS & 0.59 \\
ECOWAS and Mauritania & 0.58 \\
ECOWAS and Mauritania and CAEMU & 0.50 \\
WAEMU & 0.40 \\
CAEMU & 0.25 \\
\hline
\end{tabular}


Table 3b (continued). Regional Group Moves from CMA Average Trade-to-GDP with SADC, 1980-2000

(In percent)

\begin{tabular}{lc}
\hline \hline Liberia & 4.98 \\
Comoros & 4.92 \\
Kenya & 4.04 \\
São Tomé and Príncipe & 2.45 \\
Burundi & 2.44 \\
Madagascar & 1.82 \\
Congo, Rep. of & 1.75 \\
Rwanda & 1.29 \\
Togo & 1.27 \\
Ghana & 1.22 \\
Mali & 0.94 \\
Uganda & 0.89 \\
Nigeria & 0.83 \\
Cape Verde & 0.81 \\
Côte d'Ivoire & 0.72 \\
\hline & \\
\hline \hline CBI (Rest) & 2.53 \\
Group of five & 0.81 \\
ECOWAS & 0.76 \\
ECOWAS and Mauritania & 0.75 \\
ECOWAS and Mauritania and CAEMU & 0.69 \\
WAEMU & 0.60 \\
CAEMU & 0.49 \\
North Africa & 0.12 \\
\hline
\end{tabular}


Table 4a. Price Comovement Following Trade Dynamic from WAEMU, 1960-2000 1/

\begin{tabular}{lc}
\hline \multicolumn{1}{c}{ High Price Comovement Countries with WAEMU } \\
\hline \hline Senegal & 0.04 \\
Niger & 0.04 \\
Mali & 0.04 \\
Benin & 0.05 \\
Burkina & 0.06 \\
Togo & 0.06 \\
Côte d'Ivoire & 0.06 \\
Chad & 0.07 \\
Central African Rep. & 0.07 \\
Cameroon & 0.08 \\
Morocco & 0.10 \\
Gabon & 0.10 \\
Tunisia & 0.10 \\
Mauritania & 0.11 \\
Botswana & 0.12 \\
Mauritius & 0.12 \\
Rwanda & 0.12 \\
Lesotho & 0.12 \\
Algeria & 0.13 \\
Madagascar & 0.13 \\
South Africa & 0.13 \\
Congo, Rep. of & 0.14 \\
Malawi & 0.14 \\
Swaziland & 0.14 \\
Gurundi & 0.14 \\
Zimbia & 0.16 \\
Guinea-Bissau & 0.18 \\
Kenya & 0.18 \\
Zongo, Dem. Rep. of & 0.19 \\
Egypt & 0.19 \\
Sierra Leone & 0.21 \\
Ghana & 0.21 \\
Sigeria & 0.24 \\
\hline
\end{tabular}


Table 4a (continued). Price Comovement Following Trade Dynamic from WAEMU, 1960-2000

\begin{tabular}{lc}
\hline \multicolumn{2}{c}{ High Price Comovement Countries with ECOWAS 2/ and } \\
Mauritania
\end{tabular}

1/ The table shows the value CP, the standard error of the residual for the AR-2 regression for the log of the real exchange rate. In some cases the sample differs from 1960 to 2000.

2/ ECOWAS without Cape Verde, Liberia, and Guinea, because of lack of data. I drop country-pairs for which fewer than 18 observations are available. 
Table 4b. Price Comovement Following Trade

Dynamic from CMA, 1960-2000 1/

\begin{tabular}{lc}
\hline \multicolumn{1}{c}{ High Price Comovement Countries with CMA $2 /$} \\
\hline \hline Lesotho & 0.04 \\
South Africa & 0.05 \\
Swaziland & 0.06 \\
Botswana & 0.08 \\
Mauritius & 0.08 \\
Morocco & 0.09 \\
Tunisia & 0.09 \\
Mauritania & 0.11 \\
Burundi & 0.13 \\
Togo & 0.13 \\
Niger & 0.13 \\
Gabon & 0.13 \\
Benin & 0.13 \\
Côte d'Ivoire & 0.14 \\
Algeria & 0.14 \\
Mali & 0.14 \\
Senegal & 0.15 \\
Chad & 0.15 \\
Gambia & 0.15 \\
Congo, Rep. of & 0.15 \\
Rwanda & 0.15 \\
Zimbabwe & 0.15 \\
Madagascar & 0.16 \\
Burkina & 0.16 \\
Central African Rep. & 0.17 \\
Kenya & 0.17 \\
Cameroon & 0.18 \\
Malawi & 0.18 \\
Guinea-Bissau & 0.18 \\
Egypt & 0.18 \\
Congo, Dem. Rep. & 0.20 \\
Gierra Leone & 0.23 \\
Nigeria & 0.24 \\
Sudan & 0.31 \\
\hline
\end{tabular}


Table 4b (continued). Price Comovement Following Trade Dynamic from CMA, 1960-2000

\begin{tabular}{lc}
\hline \multicolumn{2}{c}{ High Price Comovement Countries with SADC 3/ } \\
\hline \hline Morocco & 0.07 \\
Tunisia & 0.07 \\
Mauritania & 0.09 \\
Gabon & 0.11 \\
Burundi & 0.12 \\
Niger & 0.12 \\
Benin & 0.12 \\
Togo & 0.12 \\
Algeria & 0.12 \\
Chad & 0.12 \\
Côte d'Ivoire & 0.12 \\
Rwanda & 0.13 \\
Senegal & 0.13 \\
Mali & 0.13 \\
Gambia, The & 0.13 \\
Congo, Rep. of & 0.14 \\
Madagascar & 0.14 \\
Burkina & 0.14 \\
Central African Rep. & 0.15 \\
Kenya & 0.17 \\
Cameroon & 0.17 \\
Guinea-Bissau & 0.18 \\
Egypt & 0.19 \\
Sierra Leone & 0.23 \\
Nhana & 0.31 \\
Sudan & 0.37 \\
\hline I/The tabla shaws & 0.49 \\
\hline
\end{tabular}

1/ The table shows the value CP, the standard error of the residual for the AR-2 regression for the log of the real exchange rate. In some cases the sample differs from 1960 to 2000.

2/ CMA without Namibia, because of lack of data. Remember I drop country-pairs for which fewer than 18 observations are available.

3/ SADC without Namibia, Angola, Congo, Dem. Rep. of, Mozambique, Seychelles and Tanzania, because of lack of data. Also there is no price data for São Tomé and Príncipe. 
Table 5a. Output Comovement Following Trade Dynamic from WAEMU, 1960-2000 1/

\begin{tabular}{lc}
\hline \multicolumn{1}{c}{ High Output Comovement Countries with WAEMU } \\
\hline \hline Kenya & 0.03 \\
Algeria & 0.04 \\
Egypt & 0.04 \\
Central African Rep. & 0.04 \\
Morocco & 0.04 \\
Botswana & 0.04 \\
Mauritania & 0.04 \\
Burkina & 0.04 \\
Madagascar & 0.04 \\
South Africa & 0.04 \\
Mauritius & 0.04 \\
Tunisia & 0.04 \\
Côte d'Ivoire & 0.05 \\
Mali & 0.05 \\
Gambia & 0.05 \\
Malawi & 0.05 \\
Zambia & 0.05 \\
Benin & 0.06 \\
Niger & 0.06 \\
Senegal & 0.06 \\
Ghana & 0.06 \\
Nigeria & 0.06 \\
Zimbabwe & 0.06 \\
Burundi & 0.06 \\
Sudan & 0.06 \\
Camgo, Dem. Rep. of & 0.06 \\
Swaziland & 0.06 \\
Togo & 0.06 \\
Congo, Rep. of & 0.07 \\
Lesotho & 0.07 \\
Guinea Leone & 0.08 \\
Chad & 0.08 \\
Gabon & 0.09 \\
Rwanda & 0.09 \\
\hline & 0.09 \\
& 0.11 \\
\hline
\end{tabular}


Table 5a (continued). Output Comovement Following Trade Dynamic from WAEMU, 1960-2000

High Output Comovement Countries with ECOWAS 2/ and Mauritania

\begin{tabular}{ll}
\hline \hline Madagascar & 0.03 \\
Kenya & 0.04 \\
Egypt & 0.04 \\
Morocco & 0.04 \\
Botswana & 0.04 \\
Algeria & 0.04 \\
Central African Rep. & 0.04 \\
Tunisia & 0.05 \\
Malawi & 0.05 \\
South Africa & 0.05 \\
Zambia & 0.05 \\
Zimbabwe & 0.05 \\
Swaziland & 0.06 \\
Congo, Dem. Rep. of & 0.06 \\
Burundi & 0.06 \\
Sudan & 0.06 \\
Lesotho & 0.07 \\
Congo, Rep. of & 0.07 \\
Cameroon & 0.08 \\
Gabon & 0.09 \\
Chad & 0.09 \\
Rwanda & 0.12 \\
\hline
\end{tabular}

1/ The table shows the value CY, the standard error of the residual for the AR-2 regression for the log of the ratio of real per capita GDPs. In some cases the sample differs from 1960 to 2000 .

2/ ECOWAS without Cape Verde, Liberia and Guinea. This is because of lack of data. Remember I drop country-pairs for which fewer than 18 observations are available. 
Table 5b. Output Comovement Following Trade Dynamic from CMA, 1960-2000 1/

\begin{tabular}{lc}
\hline \multicolumn{1}{c}{ High Output Comovement Countries with CMA 2/ } \\
\hline \hline South Africa & 0.04 \\
Ghana & 0.04 \\
Gambia, The & 0.04 \\
Benin & 0.04 \\
Kenya & 0.04 \\
Mauritania & 0.04 \\
Zambia & 0.05 \\
Congo, Dem. Rep. of & 0.05 \\
Madagascar & 0.05 \\
Botswana & 0.05 \\
Algeria & 0.05 \\
Tunisia & 0.05 \\
Zimbabwe & 0.05 \\
Central African Rep. & 0.05 \\
Egypt & 0.05 \\
Swaziland & 0.06 \\
Burkina & 0.06 \\
Togo & 0.06 \\
Côte d'Ivoire & 0.06 \\
Morocco & 0.06 \\
Senegal & 0.06 \\
Sierra Leone & 0.06 \\
Mali & 0.06 \\
Congo, Rep. of & 0.06 \\
Malawi & 0.06 \\
Lesotho & 0.07 \\
Murundi & 0.07 \\
Cameritius & 0.07 \\
Nigeria & 0.07 \\
Sudan & 0.07 \\
Niger & 0.07 \\
Guinea-Bissau & 0.08 \\
Gabon & 0.09 \\
Chad & 0.10 \\
Rwanda & 0.10 \\
\hline
\end{tabular}


Table 5b (continued). Output Comovement Following Trade Dynamic from CMA, 1960-2000

\begin{tabular}{lc}
\hline \multicolumn{1}{c}{ High Output Comovement Countries with SADC 3/ } \\
\hline \hline Kenya & 0.04 \\
Benin & 0.04 \\
Ghana & 0.04 \\
Gambia & 0.04 \\
Mauritania & 0.04 \\
Madagascar & 0.05 \\
Tunisia & 0.05 \\
Algeria & 0.05 \\
Egypt & 0.05 \\
Central African Rep. & 0.05 \\
Burkina & 0.05 \\
Burundi & 0.06 \\
Congo, Rep. of & 0.06 \\
Côte d'Ivoire & 0.06 \\
Togo & 0.06 \\
Morocco & 0.06 \\
Senegal & 0.06 \\
Mali & 0.06 \\
Sierra Leone & 0.06 \\
Nigeria & 0.07 \\
Cameroon & 0.07 \\
Sudan & 0.07 \\
Niger & 0.08 \\
Guinea-Bissau & 0.09 \\
Gabon & 0.09 \\
Chad & 0.10 \\
Rwanda & 0.12 \\
\hline 1/ The table shows the value CY, the standard error of the residual \\
for the AR-2 regression for the log of the ratio of real per capita \\
GDP. In some cases the sample differs from 1960 to 2000. \\
2/ CMA without Namibia. & \\
3/ SADC without Namibia, Angola, Congo, Dem. Rep. of, \\
Mozambique, Seychelles and Tanzania. This is because of lack of \\
data. & \\
& \\
&
\end{tabular}

Table 6. Average Trade to GDP Ratio with Major Currency Blocs and Europe-13, 1980-2000 (In percent)

\begin{tabular}{ccccc}
\hline & EMU 1/ & Europe-13 2/ & Japan & United States \\
\hline AFRICA & 22.15 & 26.67 & 2.42 & 6.95 \\
\hline
\end{tabular}

Source: computed using data from IMF-Direction of Trade, and WDI 2001.

1/ EMU: European Monetary Union.

2/ Europe-13: EMU and UK.

Note: Trade is imports plus exports. Import is the average of the values reported by the importer and the exporter. Idem for export. 
Figure 1. Dynamic Currency Bloc Formation Based on Individual Country Moves

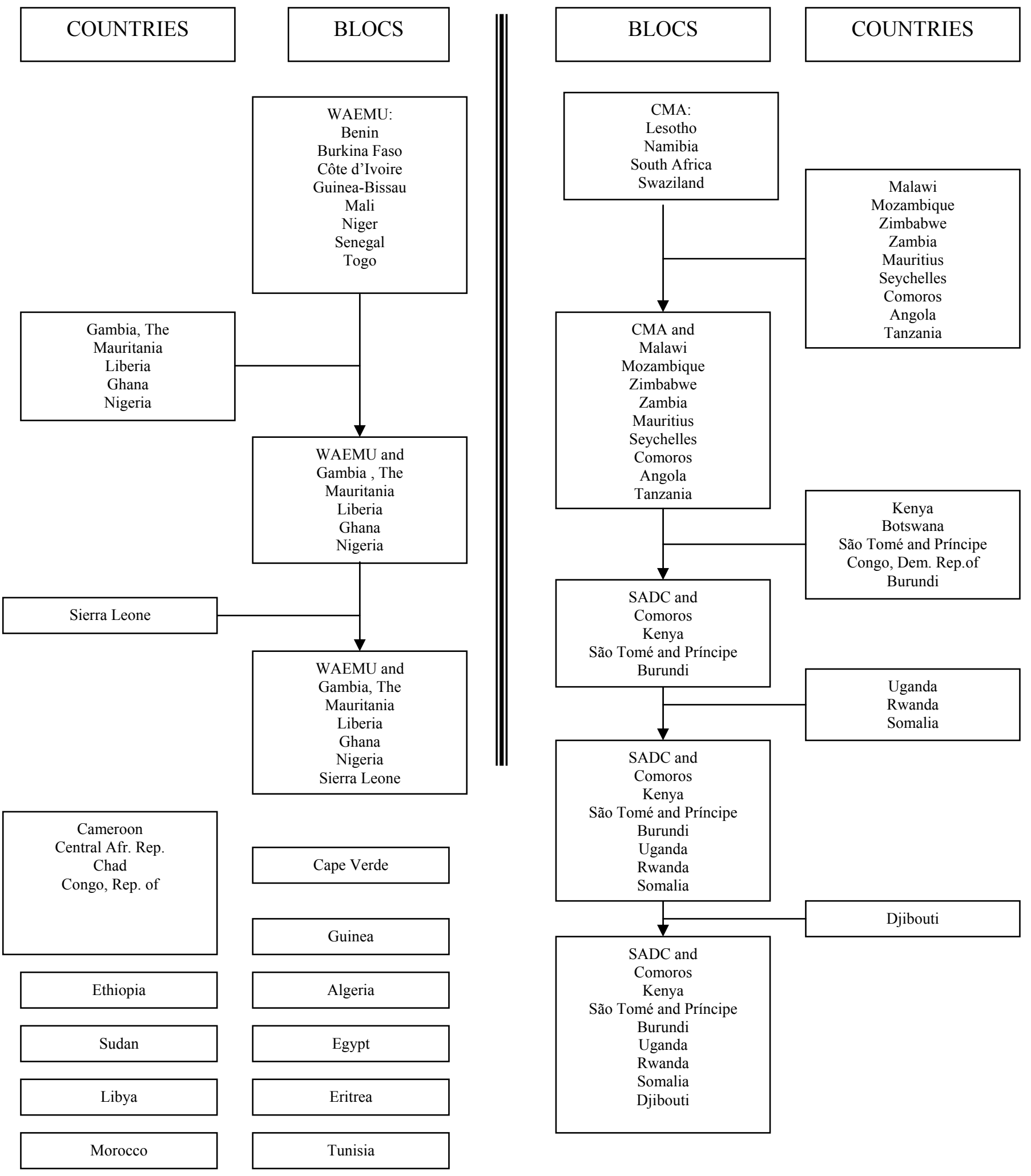


Figure 2. Membership in Major Regional Organizations

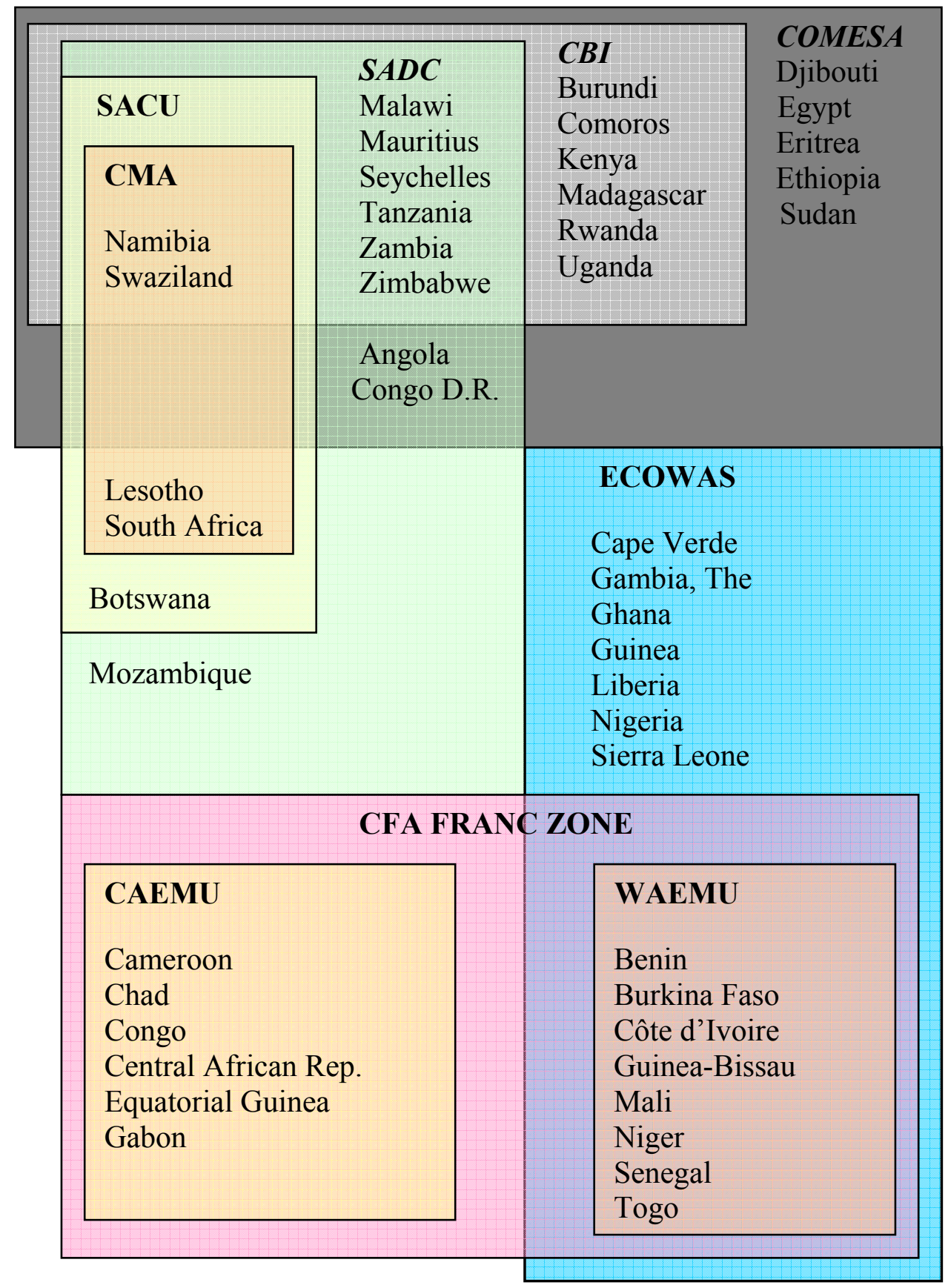


Figure 3. Dynamic Currency Bloc Formation Based on the Moves of Existing Regional Groups

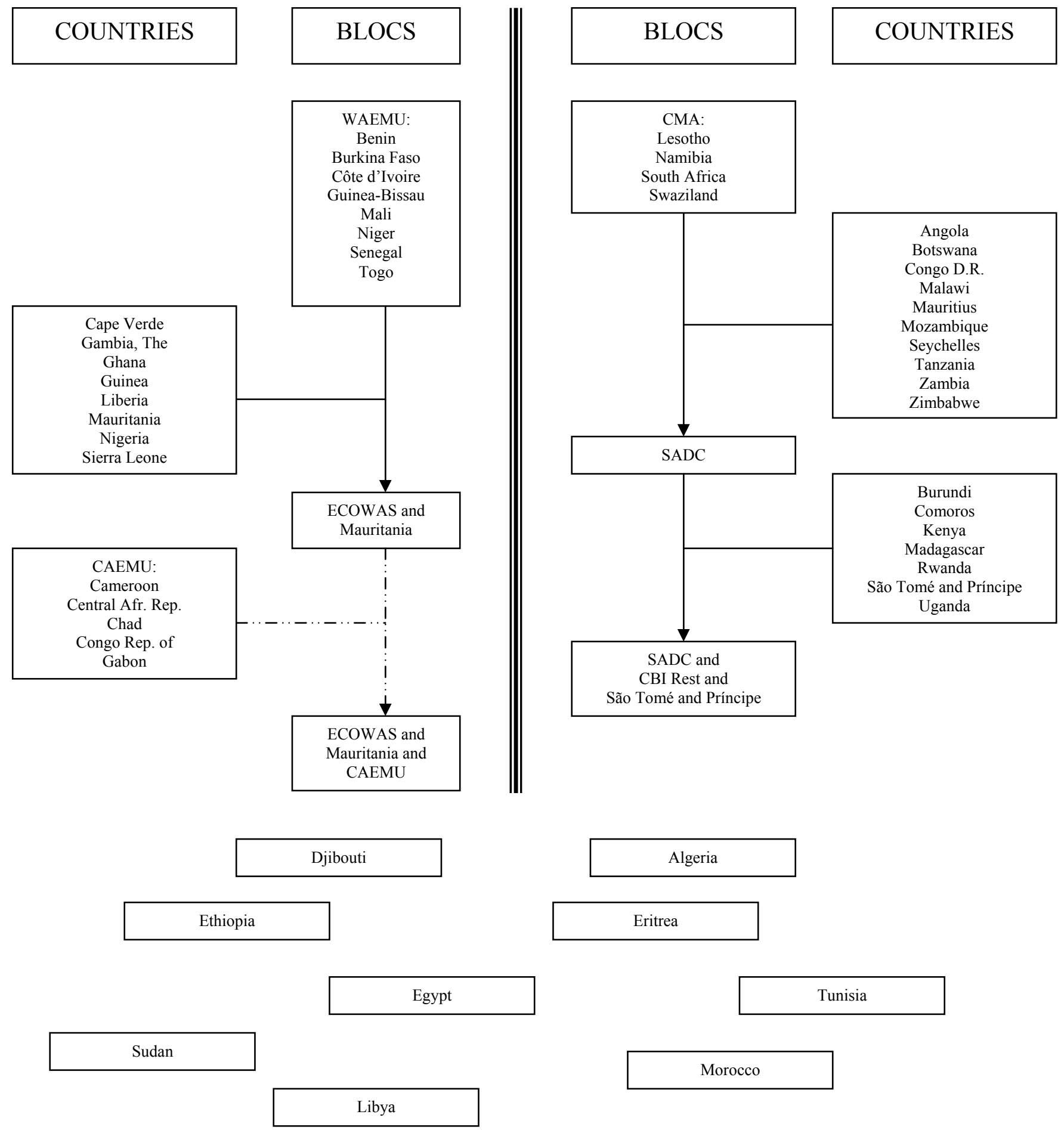




\section{Appendix}

\section{The Computation of Comovements}

To compute the comovements, I follow Alesina, Barro, and Tenreyro (2002) and pair all countries and compute the relative output $Y_{i, t} / Y_{j, t}$. For every pair $(i, j)$, I use the annual time series $\left\{\frac{Y_{i, t}}{Y_{j, t}}\right\}_{t=1960}^{2000}$ of the relative per capita GDP, to compute the second-order autoregression: ${ }^{1}$

$$
\ln \frac{Y_{i, t}}{Y_{j, t}}=a_{o}+a_{1} \ln \frac{Y_{i, t-1}}{Y_{j, t-1}}+a_{2} \ln \frac{Y_{i, t-2}}{Y_{j, t-2}}+\varepsilon_{t i j}
$$

The estimated residual $\hat{\varepsilon}_{t i j}$, measures the relative output that would not be predictable from the two prior values of relative outputs. Hence as a measure of lack of comovement of relative output, I use the root-mean-squared error:

$$
C Y_{i j}=\sqrt{\frac{1}{T-3} \sum_{t=1}^{t=T} \hat{\varepsilon}_{t i j}^{2}}
$$

The lower the value of $C Y_{i j}$, the greater the comovement of outputs between countries $i$ and $j$.

Proceeding analogously, I compute a measure of lack of comovement of relative prices from the second-order autoregression on annual data for relative price:

$$
\ln \frac{P_{i, t}}{P_{j, t}}=b_{o}+b_{1} \ln \frac{P_{i, t-1}}{P_{j, t-1}}+b_{2} \ln \frac{P_{i, t-2}}{P_{j, t-2}}+u_{t i j}
$$

Similar to the case of output, the measure of lack of comovement of relative prices is computed as the root-mean-squared error:

$$
C P_{i j}=\sqrt{\frac{1}{T-3} \sum_{t=1}^{t=T} \hat{u}_{t i j}^{2}}
$$

The lower the value of $C P_{i j}$, the greater the comovement of prices between countries $i$ and $j$.

\footnotetext{
${ }^{1}$ I use fewer observations when the full time series from 1960 to 2000 is not available. However, I drop country-pairs for which fewer than 18 observations are available.
} 


\section{REFERENCES}

Alesina, Alberto, and Robert J. Barro, 2002, “Currency Unions,” Quarterly Journal of Economics, Vol. 117 (May), pp. 409-36. and Silvana Tenreyro, 2002, "Optimal Currency Areas," in NBER Macroeconomic Annual, ed. by Mark Gertler and Kenneth Rogoff (Cambridge, Massachusetts: MIT Press).

Alesina, Alberto, and Vittorio Grilli, 1992, “The European Central Bank: Reshaping Monetary Politics in Europe," in Establishing a Central Bank: Issues in Europe and Lessons from the US, ed. by Matthew Canzoneri, Vittorio Grilli, and Paul Masson (Cambridge, England: Cambridge University Press).

Barro Robert J., and Silvana Tenreyro, 2003, "Economic Effects of Currency Unions," NBER Working Paper No. 9435 (Cambridge, Massachusetts: National Bureau of Economic Research).

Bayoumi, Tamin, 1994, “A Formal Model of Optimal Currency Areas," Staff Papers International Monetary Fund, Vol. 41 (December), pp. 537-54.

and Barry Eichengreen, 1992, "Shocking Aspects of European Monetary Integration," NBER Working Paper No. 3949 (Cambridge, Massachusetts: National Bureau of Economic Research).

Broda, Christian, 2004, "Terms of Trade and Exchange Rate Regimes in Developing Countries," Journal of International Economics, Vol. 63 (May), pp. 31-58.

Cohen, Benjamin J., 2003, "Monetary Union: The Political Dimension," in The Dollarization Debate, ed. by James W. Dean, Dominic Salvatore, and Thomas D. Willett (Oxford: Oxford University Press).

1993, "Beyond EMU: The Problem of Sustainability," Economics and Politics, Vol. 5 (July), pp. 187-202.

de Grauwe, Paul, and Wim Vanhaverbeke, 1993, "Is Europe an Optimal Currency Area? Evidence from Regional Data," in Policy Issues in the Operation of Currency Unions, ed. by Paul Masson and Mark P. Taylor (Cambridge, England: Cambridge University Press).

Devarajan, Shanta, and Jaime de Melo, 1987, "Evaluating Participation in African Monetary Unions: A Statistical Analysis of the CFA Zones," World Development, Vol. 15 (April), pp. 483-96. 
Economic Community of West African States (ECOWAS), 1980, Unrecorded Trade Flows within ECOWAS, Report prepared for ECOWAS Trade Customs and Monetary Study Project by the United Nations Economic Commission for Africa and the Economic and Social Council, E/CN.14, Working Paper 1/115.

Eichengreen, Barry, 1993, “European Monetary Unification,” Journal of Economic Literature, Vol. 31 (September), pp. 1321-57.

Foroutan, Faezeh, and Lant Pritchett, 1993, "Intra Sub-Saharan African Trade: Is It Too Little?" Journal of African Economies, Vol. 2 (May), pp. 74-105.

Feldstein, Martin, 1997, "The Political Economy of the European Economic and Monetary Union: Political Sources of an Economic Liability," Journal of Economic Perspectives, Vol. 2 (Fall), pp. 23-42.

Frankel, Jeffrey, 1997, Regional Trading Blocs in the World Economy (Washington: Institute for International Economics). and Andrew K. Rose, 1998, "The Endogeneity of the Optimum Currency Area Criteria," Economic Journal, Vol. 108 (July), pp. 1009-25.

2002, "An Estimate of the Effect of Common Currencies in Trade and Income," Quarterly Journal of Economics, Vol. 117 (May), pp. 437-66.

Glick, Reuven, and Andrew K. Rose, 2002, "Does a Currency Union Affect Trade? The Time Series Evidence,” European Economic Review, Vol. 46 (June), pp. 1125-51.

Krugman Paul, 1993, "Lessons of Massachusetts for EMU," in The Transition to Economic and Monetary Union in Europe, ed. by Francisco Torres and Francesco Giavazzi (Cambridge, England: Cambridge University Press).

Masson, Paul, and Catherine Pattillo, 2001, Monetary Union in West Africa (ECOWAS): Is It Desirable and How Could It Be Achieved? IMF Occasional Paper No. 204 (Washington: International Monetary Fund).

Mundell, Robert, 1961, “A Theory of Optimum Currency Areas,” American Economic Review, Vol. 51 (November), pp. 657-65.

Ogunkola E. Olawale, 2000, "Evaluation of the Viability of a Single Monetary Zone in ECOWAS," A final Report presented at the Biannual Research Workshop of the African Economic Research Consortium, (AERC), Nairobi, Kenya.

2002, "The Second Monetary Zone in West Africa and the Future of a Single Monetary Zone in sub-Saharan Africa" (unpublished, National University of Lesotho). 
Rose, Andrew K., 2000, “One Money, One Market: Estimating the Effect of Common Currencies on Trade," Economic Policy, Vol. 15 (April), pp. 9-45.

Sparks, Donald L., 2002, “The Future of Monetary Integration in Southern Africa: Will SADC Join the Rand Monetary Area?" (unpublished; Toronto: Ryerson University).

von Hagen, Jurgen and Manfred J. M. Neumann, 1994, "Real Exchange Rates Within and between Currency Areas: How Far is EMU?", The Review of Economics and Statistics, Vol. 76 (May), pp. 236-44.

Yehoue, Etienne B., 2004, "Currency Bloc as a Dynamic Process Based on Trade Network Externalities,” IMF Working Paper 04/222, (Washington: International Monetary Fund), November. 